\title{
EVALUATION OF MOBILE APPLICATION BPJSTKU USING COBIT 5 FRAMEWORK (STUDY CASE: BPJS KETENAGAKERJAAN)
}

\author{
Winarto Babo $^{1}$ and Metty Mustikasari ${ }^{1}$ 更 \\ ${ }^{1}$ Department Management Information System, Gunadarma University, Indonesia
}
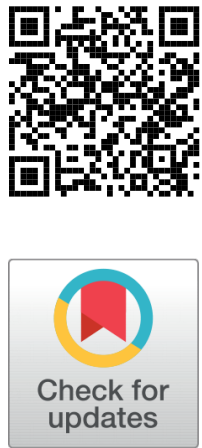

Received 20 June 2021

Accepted 3 July 2021

Published 31 July 2021

Corresponding Author

Winarto Babo,winarto.babo@gm

ail.com

DOI $10.29121 /$

ijetmr.v8.i7.2021.963

Funding: This research received no specific grant from any funding agency in the public, commercial, or not-for-profit sectors.

Copyright: (C) 2021 The Author(s). This is an open access article distributed under the terms of the Creative Commons Attribution License, which permits unrestricted use, distribution, and reproduction in any medium, provided the original author and source are credited.

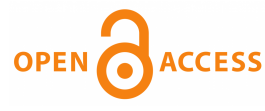

\section{ABSTRACT}

BPJS Ketenagakerjaan as a social security to provides protection to all workers in Indonesian utilize technlogy especially mobile application in providing information and services to all BPJS Ketenagakerjaan customer anytime and anywhere without having to BPJS Ketenagakerjaan branch office. Beginning in 2019 BPJS Ketenagakerjaan has redevelop mobile application with the name BPJSTKu as a continuation of BPJSTK Mobile has been made previously. The addition of new features and improvements to the mobile application BPJSTKu apparently still provides problem and complaints from workers addressed to the BPJS Ketenagakerjaan branch office, BPJS Ketenagakerjaan complaints services, and BPJS Ketenagakerjaan contact center. For this reason, it's necessary to evaluate the implementation of mobile application BPJSTKu as a whole to assist BPJS Ketenagakerjaan in a achieving the objectives to improving IT governance and management of BPJS Ketenagakerjaan. This study aims to evaluate the mobile application BPJSTKu using the COBIT 5 framework which has been implemented in BPJS Ketenagakerjaan. In this case the evaluation will be carried out using the deliver, service, and support (DSS) domain and the domain monitor, evaluate, and assess (MEA) which in the end will be measured the capability level as well as recommendations for improvement and gap analysis on the mobile application BPJSTKu.

Keywords: COBIT5, DSS, MEA, Mobile Application, BPJSTKu, BPJS Ketenagakerjaan

\section{INTRODUCTION}

Currently, information technology in business or an organization occupies a very important and crucial role, apart from being a tool in an effort to win the competition, information technology is the most important part in supporting the achievement of the organization's strategic plans both short and long term, the vision and mission of the organization, and the organization's goals. The development of technology that continues to develop also encourages the development of mobile applications which are currently widely used in various organizations, the application of 
this has turned out to have a positive impact on organizations where convenience, speed, and a better experience are some of the things that encourage organizations to continue to develop mobile applications Islam et al. (2010). BPJS Employment as an agency that provides social security and provides protection to all workers in Indonesia also utilizes information technology, especially mobile applications in providing information and services to all BPJS Employment participants with access to information anytime and anywhere without having to come to the BPJS Employment Branch Office. The first version of the mobile application that has been implemented by BPJS Employment is BPJSTK Mobile, which was launched in 2014 with quite simple features, namely checking the balance of the Old Age Security (JHT), Details of the Old Age Security Balance (RSJHT), the balance of the Pension Guarantee (JP), and other membership information.

Along with the development of information and the needs of users of BPJS Employment participants, the continuation of the previous version under the name BPJSTKu, there are several new features added to the application such as checking balances for Non-Wage Recipients (BPU), Indonesian Migrant Workers (PMI), registration of BPJS Employment participants. (PU, BPU, PMI), reporting and complaints, real-time work accident reporting, and digital cards for BPJS Employment participants. All of these features are not yet available in BPJSTK Mobile, but have been redeveloped on BPJSTKu which was implemented in early 2019. The addition and improvement of new features on the BPJSTKU mobile application is still causing problems and complaints from workers who are directed to the BPJS Employment Branch Office, BPJS Employment complaint service, and BPJS Employment contact center. Some of the problems that often occur in the BPJSTKu mobile application are the failure to register new participants who want to use BPJSTKu, frequent problems with the electronic submission menu for BPJS Employment claims (e-claims), and the absence of electronic balances, both old-age guarantee balances (JHT) and balance details. old age insurance (RSJHT) for participants who have more than 1 BPJS Employment participant card.

Several of problems that have existed to date, BPJS Ketenagakerjaan is considered to be still quite slow in handling problems and complaints related to the BPJSTKu mobile application that has been used by BPJS Ketenagakerjaan participants. This is because to deal with existing problems, it takes time and must go through the BPJS Employment helpdesk channel which can only be done by the Information Technology Intermediary (PMTI) Branch Offices, while the BPJSTKu mobile application was developed to make it easier for BPJS Employment participants in terms of accessing information and services. BPJS Employment in real time, which is expected to make it easier and provide a better experience for BPJS Employment participants. The implementation of information technology for mobile applications can also be evaluated, using the COBIT 5 framework which is a development of COBIT 4.1. According to Putri (2016) COBIT 5 is a comprehensive framework that can help companies achieve their goals for corporate IT governance and management. To evaluate infor- 
mation technology in BPJS Employment, the COBIT 5 framework is one solution that can be done to help companies create optimal value from IT by maintaining a balance between profit and optimizing risk and the use of existing resources.

Research related to evaluating information technology for mobile applications using the COBIT 5 framework has been carried out Ulfatisa et al. (2018) to measure the capability level in the previous version of the mobile application, namely BPJSTK Mobile at BPJS Employment at the Mataram Branch Office. In this study the author uses the Deliver, Service, and Support (DSS) domain, and the result is that there are 2 processes that have capability level 2, namely DSS01 and DSS02, while DSS03, DSS04, DSS05, and DSS06 are at capability level 1. Overall capability level based on the average assessment is at level 1, namely (Performed process), which means it has been implemented but there is no standard of application in carrying out the process, has not been documented, and communicated well. In addition to this, the researcher also suggests using other domains in the COBIT 5 framework, namely Evaluate, Direct, Monitor (DEM), Align, Plan, organize (APO), Build, Acquire, implement (BAI), and Monitor, Evaluate, and Assess (MEA) for further research.

In this case, to find out the level of capability of the BPJSTKu mobile application, especially in the DSS and MEA domains, the existing conditions of each existing domain, as well as to provide recommendations regarding things that need to be improved or improved on the BPJSTKu service, so that it can provide accelerated information and services. BPJS Employment participants. For this reason, researchers will evaluate the BPJSTKu Mobile Application Using the COBIT 5 Framework (Case Study: BPJS Ketenagakerjaan).

\section{MATERIALS AND METHODS}

The research methodology to be carried out is described as follows:

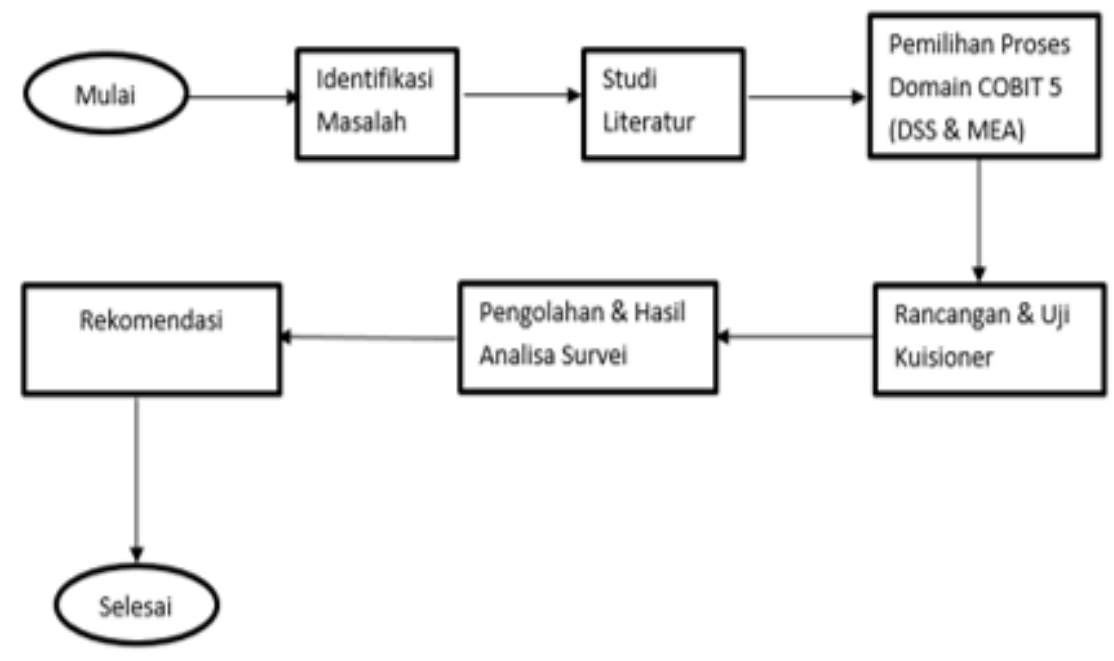




\subsection{RESEARCH LOCATION AND TIME}

This research was conducted on one of the BPJS Employment service channels, namely BPJSTKu which is a mobile app and is used by BPJS Employment participants. Held at the Head Office and Regional Offices in August 2019.

\subsection{COBIT DOMAIN PROCESS SELECTION}

In selecting the COBIT domain process, there are several stages that must be carried out, these things include:

- Mapping COBIT 5 Enterprise Goals with IT BPJS Employment mission

- Mapping of IT Related Goals with the mission of BPJS Employment

- Mapping IT COBIT 5 Processes with IT Related Goals

a. Mapping COBIT 5 Enterprise Goals with BPJS Employment IT Mission

\begin{tabular}{|c|c|c|}
\hline $\begin{array}{l}\text { Perspektif } \\
\text { Balanced } \\
\text { Scorecard (BSC) }\end{array}$ & Indikator KPI (Enterprise Goals) & $\begin{array}{l}\text { Misi IT BPJS } \\
\text { Ketenagakerjaan }\end{array}$ \\
\hline \multirow{5}{*}{ Keuangan } & 1. Nilai Stakeholder Investasi Bisnis & \\
\hline & 2.Portfolio dari produk dan pelayanan yang kompetitif & \\
\hline & 3.Pengelolaan Risiko Bisnis & \\
\hline & 4.Kepatuhan terhadap hukum dan peraturan eksternal & \\
\hline & 5.Transparansi Keuangan & Transparency \\
\hline \multirow{5}{*}{ Pelanggan } & 6.Budaya pelayanan berorientasi pada pelanggan & Service \\
\hline & 7.Kelangsungan dan ketersediaan pelayanan bisnis & Simplify, Unify, Nenwork \\
\hline & 8.Respon yang cepat terhadap perubahan bisnis & Agile \\
\hline & 9.Strategi pengambilan keputusan berdasar informasi & \\
\hline & 10.Optimasi biaya pelayanan & \\
\hline \multirow{5}{*}{ Internal } & 11.Optimasi fungsional proses bisnis & \\
\hline & 12. Optimasi biaya proses bisnis & \\
\hline & 13. Mengelola perubahan program bisnis & \\
\hline & 14.Produktifitas operasional dan staf & \\
\hline & 15.Kepatuhan kebijakan internal & \\
\hline \multirow{2}{*}{$\begin{array}{l}\text { Pertumbuhan \& } \\
\text { Pembelajaran }\end{array}$} & 16. Orang terampil dan termotivasi & \\
\hline & 17. Produk dan inovasi budaya bisnis & Innovation \\
\hline
\end{tabular}


b. Mapping Results Between Enterprise Goals and BPJS Employment IT Mission

\begin{tabular}{|l|l|l|}
\hline $\begin{array}{l}\text { Perspektif } \\
\text { Balanced } \\
\text { Scorecard (BSC) }\end{array}$ & Indikator KPI (IT Related Goals) & $\begin{array}{l}\text { Misi IT BPJS } \\
\text { Ketenagakerjaan }\end{array}$ \\
\hline Keulangan & 5.Transparansi Keuangan & Transparency \\
\hline \multirow{4}{*}{ Pelanggan } & $\begin{array}{l}\text { 6.Budaya pelayanan berorientasi pada } \\
\text { pelanggan }\end{array}$ & Service \\
\cline { 2 - 4 } & $\begin{array}{l}\text { 7.Kelangsungan dan ketersediaan } \\
\text { pelayanan bisnis }\end{array}$ & Simplify, Unify, Network \\
\cline { 2 - 4 } & $\begin{array}{l}\text { 8.Respon yang cepat terhadap perubahan } \\
\text { bisnis }\end{array}$ & Agile \\
\cline { 2 - 4 } & $\begin{array}{l}\text { 17. Produk dan inovasi budaya bisnis } \\
\text { Innovation }\end{array}$ \\
\hline
\end{tabular}

c. Mapping IT Related Goals with BPJS Employment Mission

\begin{tabular}{|c|c|c|}
\hline 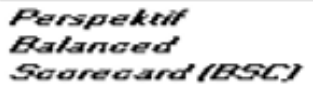 & IT Aokared Goak & G. Serrover \\
\hline \multirow{6}{*}{ Keuangan } & Kesuaian strategi TI dan bisnis & $\mathbf{P}$ \\
\hline & $\begin{array}{l}\text { Kepatuhan Tl dan dukungan untuk bisnis } \\
\text { dengan hukum dan peraturan eksternal }\end{array}$ & \\
\hline & $\begin{array}{l}\text { Komitmen manajemen untuk membuat } \\
\text { keputusan TI }\end{array}$ & \\
\hline & Mengelola risiko terkaik TI & \\
\hline & $\begin{array}{l}\text { Memanfaatkan investasi TI terkait layanan } \\
\text { portofolio }\end{array}$ & $\mathbf{S}$ \\
\hline & Transparansi biaya TI, keuntungan, \& risiko & \\
\hline \multirow{2}{*}{ Pelanggan } & $\begin{array}{l}\text { Layanan } \mathrm{TI} \text { sejalan dengan kebutuhan } \\
\text { bisnis }\end{array}$ & $\mathbf{P}$ \\
\hline & $\begin{array}{l}\text { Penggunaan aplikasi, informasi, dan solusi } \\
\text { teknologi yang menoukupi }\end{array}$ & $\mathbf{S}$ \\
\hline \multirow{7}{*}{ Internal } & Kehandalan TI & 5 \\
\hline & $\begin{array}{l}\text { Keamanan informasi, pengelolaan } \\
\text { infrastruktur, dan aplikasi }\end{array}$ & \\
\hline & $\begin{array}{l}\text { Optimasi asset TI, sumber daya, dan } \\
\text { kemampuan }\end{array}$ & \\
\hline & $\begin{array}{l}\text { Mendukung proses bisnis dengan } \\
\text { menggabungkan aplikasi dan teknologi } \\
\text { dalam proses bisnis }\end{array}$ & $\mathbf{S}$ \\
\hline & $\begin{array}{l}\text { Program yang memberikan manfaat, tepat } \\
\text { waktu, anggaran, pemenuhan kebutuhan, } \\
\text { dankualitas standar }\end{array}$ & $\mathbf{5}$ \\
\hline & $\begin{array}{l}\text { Ketersediaan informasi yang bisa } \\
\text { diandalkan dan digunakan untuk } \\
\text { pengembilan keputusan manajemen }\end{array}$ & \\
\hline & Kepatuhan TI terhadap kebijakan internal & \\
\hline \multirow{2}{*}{$\begin{array}{l}\text { Pertumbuhan \& } \\
\text { Permbelajaran }\end{array}$} & $\begin{array}{l}\text { Personil Tl yang kompeten, motivasi bisnis, } \\
\text { dan TI }\end{array}$ & $\mathbf{S}$ \\
\hline & $\begin{array}{l}\text { Pengetahuan, keahlian, dan inisiatif untuk } \\
\text { inovasi bisnis }\end{array}$ & $\mathbf{S}$ \\
\hline
\end{tabular}


d. Mapping IT COBIT 5 Processes with IT Related Goals

\begin{tabular}{|l|c|}
\hline COBIT 5 & IT Related Goals \\
\hline Mengelola Operasional & P \\
\hline Mengelola Permintaan Layanan \& Insiden & P \\
\hline Mengelola Masalah & P \\
\hline Mengelola Kelangsungan & P \\
\hline Mengelola Pelayanan Keamanan & S \\
\hline Mengelola Kontrol Proses Bisnis & P \\
\hline Memonitor, mengevaluasi, dan menilai kinerja & P \\
\hline Memonitor, mengevaluasi, dan menilai sistem kontrol internal & S \\
\hline Memonitor, mengevaluasi, dan menilai kepatuhan eksternal & S \\
\hline
\end{tabular}

\subsection{QUESTIONNAIRE DESIGN AND TEST}

- Questionnaire Design

the design of the questionnaire was determined step by step related to the selection of the COBIT domain by looking at the existing IT related goals/IT processes with the connection between the objects to be carried out, namely the BPJSTKu mobile apps.

- Questionnaire Test

In the questionnaire test, distribution will be carried out to the Assistant Deputy Director of the Field Both in IT Development and in IT Operations, BPJS Employment IT Staff with reference to the DSS domain and COBIT 5 MEA framework. Overall, the author will evaluate the BPJSTKu mobile application through a questionnaire. which has been distributed by asking for his opinion regarding BPJSTKu services, each statement in the questionnaire refers to the objective control of each existing sub-domain. The instrument to be used is in the form of a Likert scale with five levels of weight consisting of: Strongly disagree with weight $=1$, disagree with weight $=$ 2 , don't know $=0$, Agree $=4$, Strongly agree $=5$.

- Processing and Results of Survey Analysis

Survey data processing is carried out in 2 ways, namely the attribute maturity index and the maturity index (Boyke Nurhidaya, 2014). In calculating the attribute maturity index, it is obtained from the total respondents who answered from each scale multiplied by the weight of the scale then divided by the number of respondents. The formula is as follows: 


\section{Indeks kematangan atribut $=\sum($ Total Jawaban $x$ Bobot $) /$ Jumlah Responden}

As for the calculation of the maturity index, the formula is as follows:

\section{Indels kematangan $=\sum$ Indels Kematangan Atribut $/ \sum$ Aktifitas (6)}

- Maturity Index Representation

After getting the results from the attribute maturity index and the maturity index, a representation of each existing sud domain will be obtained, namely the Deliver, Service, and Support (DSS) domain and the Monitor, Evaluate, and Assess (MEA) domain, this can be seen on

\begin{tabular}{|c|l|}
\hline Indeks Kematangan & \multicolumn{1}{|c|}{ Level Kematangan } \\
\hline $0-0,51$ & 0-Non-Existent \\
\hline $0,51-1,50$ & 1-Initial/ad Hoc \\
\hline $1,51-2,50$ & 2-Repeatable But Intuitive \\
\hline $2,51-3,50$ & 3-Defined Process \\
\hline $3,51-4,50$ & 4-Managed and Measurable \\
\hline $4,51-5,00$ & 5-Optimized \\
\hline
\end{tabular}


- Recommendations

From the entire series of evaluations related to BPJSTKu mobile apps, by looking at the existing capability level with the set targets, it is hoped that it can provide input and recommendations for better BPJSTKu improvements in the future, for the sake of convenience and acceleration of improvement acceleration for users/ BPJSTKu participants.

\section{RESULTS AND DISCUSSIONS}

\subsection{RESPONDENT PROFILE}

The profiles of respondents in this study are BPJS Employment employees consisting of employees from the head office and regional offices whose daily tasks and duties are related to IT at BPJS Employment, especially those that are directly or indirectly related to the BPJSTKu mobile application. In this study, there were 51 respondents who gave their opinions regarding the BPJSTKu mobile application.

\subsection{EVALUATION RESULTS OF THE BPJSTKU MOBILE APPLICATION}

\begin{tabular}{|l|c|c|c|}
\hline \multicolumn{1}{|c|}{ Domain } & $\begin{array}{c}\text { Hasil } \\
\text { Evaluasi }\end{array}$ & $\begin{array}{c}\text { Level } \\
\text { Kematangan }\end{array}$ & $\begin{array}{c}\text { Target IT } \\
\text { Maturity }\end{array}$ \\
\hline $\begin{array}{l}\text { DSS01 Manage Operation } \\
\text { DSS02 Manage Service Request \& } \\
\text { Incidents }\end{array}$ & 3,77 & 3 & 4 \\
\hline DSS03 Manage Problem & 2,47 & 4 & 4 \\
\hline DSS04 Manage Continuity & 4,20 & 4 & 4 \\
\hline $\begin{array}{l}\text { DSS05 Manage Security Services } \\
\text { Manage Business Process }\end{array}$ & 3,204 & 4 & 4 \\
\hline $\begin{array}{l}\text { DSS06 } \\
\text { Control }\end{array}$ & & 3 & 4 \\
\hline $\begin{array}{l}\text { MEA01 Monitor, Evaluate, and Assess } \\
\text { The System of Internal Control }\end{array}$ & 2,72 & 3 & 4 \\
\hline
\end{tabular}


The current evaluation results for DSS domains that reach the IT Maturity level 4 target are 3 subdomains, firstly DSS02 manage service requests \& incidents with a value of 3.63, secondly DSS04 manage continuity with a value of 4.20 , and thirdly DSS05 manage security services with a value of 4.04 , while for MEA there is only 1 subdomain, namely MEA02 monitor evaluate and assess the system of internal control with a value of 4.20, and for other subdomains it is still under the IT Maturity Level target of BPJS Ketenagakerjaan in 2019.

- DSS01 Domain Results

The evaluation result for the DSS01 manage operation domain is at a value of 2.77, where every process in the manage operation domain has been defined and confirmed as a standard business process.

- DSS02 Domain Results

The evaluation results for the DSS02 domain manage service requests \& incidents are at a value of 3.63 , where every process in the domain manage service requests $\&$ incidents has been quantitatively managed in accordance with metrics / things that are mutually agreed upon.

- DSS03 Domain Results

The evaluation results for the DSS03 manage problem domain are at a value of 2.47, where every process in the manage problem domain has been adequately documented so that the same steps can be taken.

- DSS04 Domain Results

The evaluation results for the DSS04 manage continuity domain are at a value of 4.20, where every process in the manage continuity domain has been managed quantitatively in accordance with mutually agreed metrics/things.

- DSS05 Domain Results

The evaluation result for the DSS05 managed security services domain is at a value of 4.04, where every process in the manage continuity domain has been managed quantitatively in accordance with mutually agreed metrics/things.

- DSS06 Domain Results

The evaluation result for the DSS06 manage business process control domain is at a value of 3.20, where every process in the manage business process control domain has been defined and confirmed as a standard business process. 


\section{- MEA01 Domain Results}

The evaluation results for the MEA01 domain monitor, evaluate, and assess performance and conformance are at a value of 2.72 , where every process in the monitor, evaluate, and assess performance and conformance domain has been defined and confirmed as a standard business process.

- MEA02 Domain Results

The evaluation results for the MEA02 domain monitor, evaluate, and assess performance and conformance are at a value of 4.20 , where every process in the monitor, evaluate, and assess performance and conformance domain has been managed quantitatively in accordance with agreed metrics/things together.

\section{CONCLUSIONS AND RECOMMENDATIONS}

\subsection{CONCLUSION}

Based on the results of the evaluation that has been carried out regarding the BPJSTKu mobile application using the COBIT 5 framework, it can be concluded several things as follows:

- An evaluation has been carried out regarding 2 existing domains in COBIT 5, namely deliver, service, and support (DSS) with 6 existing subdomains namely DSS01, DSS02, DSS03, DSS04, DSS05, DSS06 and monitor, evaluate, and assess (MEA) with 2 existing subdomains are MEA01 and MEA01.

- Of the 8 subdomains that have been evaluated, there are 5 subdomains that are still below the IT Maturity level target, namely DSS01 with a value of 2.77, DSS02 with a value of 3.63, DSS03 with a value of 2.47, DSS06 with a value of 3.20 , and MEA01 with a value of 2.72. Meanwhile, the other 3 subdomains have reached the target, namely DSS04 with a value of 4.20, DSS05 with a value of 4.04, and MEA02 with a value of 4.20 .

- The average assessment for the delivery, service, and support (DSS) domain is at a value of 2.85 with a maturity level of "Defined Process, and for the monitor, evaluate, and assess (MEA) domain it is at a value of 3.46 with the same maturity level, namely 3 "Defined Processes" where for both domains the entire existing process has been defined and confirmed as standard business processes.

- Broadly speaking, the problems from each domain/subdomain that have not been achieved are related to data, while in terms of security and infrastructure they already have good scores in terms of assessment but for both of these things still need to be improved to continue to maintain the consistency of the BPJSTKu mobile apps service channel. 


\subsection{RECOMMENDATION}

From the evaluation results, the following suggestions for improvements/improvements can be made for the BPJSTKu mobile application:

- The BPJSTKu mobile application should be evaluated as a whole using the existing domains in COBIT 5, including the domains that have not been carried out, namely evaluate, direct, and monitor (EDM), align, plan, and organize (APO), and build, acquire, and implement (BAI).

- To achieve the IT Maturity level target that has been set, which is 4 , it is necessary to do a quick win related to low-value processes and carry out periodic monitoring, both 6 months and in the next year.

- It is necessary to form a special team (ad-hoc) specifically to conduct analysis related to improvements and things that need to be improved regarding the BPJSTKu mobile apps.

- Make improvements with two things, namely based on the priority scale to be achieved by the team or based on the lowest value of each existing domain/subdomain.

- In achieving and determining the existing business strategy in BPJSTKu, it is necessary to carry out intense communication to each related unit/individual, and involve the BPJS Employment IT steering committee, so that proposals and input are obtained in accordance with the direction of the organization, both the IT Masterplan BPJS Employment and the BPJS Employment Strategic Plan. overall

\section{REFERENCES}

C, J. F. K. (2018). Audit Menggunakan Cobit 4.1 Dan Cobit 5 Dengan Case Study, Teknosain, Indonesia.

Davis, G. B. (1998). Kerangkadasar Sistem Informasi Manajemen: Pengantar Seri Manajemen No: 90. A, Pt. Pustaka Binaman Pressindo.

Ekowansyah, E., Puspita, Y. H. C., \& Sabrina. (2017). Audit Sisteminformasiakademikmenggunakan Cobit 5 Di Universitas Jendral Achmad Yani, Seminar Nasional Komputerdan Informatika (Senaski).

Gondodiyoto. (2007). Audit Sistem Informasi + Pendekatan Cobit, Mitra Wacana Media, Jakarta.

Isaca. (2012). Cobit 5 A Business Framework For Governance And Management Of Enterprises It, It Governance Institute, Usa.3.

Islam, M. R., Islam, M. R., \& Mazumder, T. A. (2010). Mobile Application And Its Global Impact. International Journal Of Engineering \&Technolgy, Bangladesh..

Matthews, J. R. (2007). The Evaluation And Measurement Of Library Services, Libraries Unlimited, United States.

Nugroho, H. (2017). Proposed IT Governance at Hospital Based on COBIT 5 Framework. IJAIT (International Journal of Applied Information Technology), 1(02), 52-58. Retrieved from https://dx.doi.org/10.25124/ijait.v1i02.875 10.25124/ijait.v1i02.875 
Nurhidayat, B. (2011). Evaluasi Integrated Toll Collection System Dengan Menggunakan Framework Cobit. Program Pasca Sarjana Institut Pertanian Bogor.

Nyoman, A. P., Eko, D., \& Kemas, R. (2014). Evaluasi Sistem E-Government Kota Denpasar Menggunakan Framework Cobit 5 Pada Domain Monitor, Evaluate, And Assess (Mea), Universitas Kristen Satya Wacana, Salatiga.

Omari, L. A., Barnes, D. P., \& Pitman, D. G. (2012). Optimising Cobit 5 For It Governance: Examples From Public Sector, International Conference On Applied And Theoritical Information System Research, Taiwan..

Putri, M. (2016). Evaluasi Tata Kelola Teknologi Informasi Menggunakan Kerangka Cobit 4.1 (Studikasus: Bidang Kominfo Dishub Kominfo Kota Kediri), Universitas Brawijaya.

Ulfatisa, C., Ismiarta, A., Reza, A., \& P. (2018). Evaluasilayanan Bpjstk Mobile Denganmenggunakan Domain Deliver, Service, And Supportberdasarkan Framework Cobit 5 (Studi Kasus: Bpjs Ketenagakerjaan Cabang Mataram). 